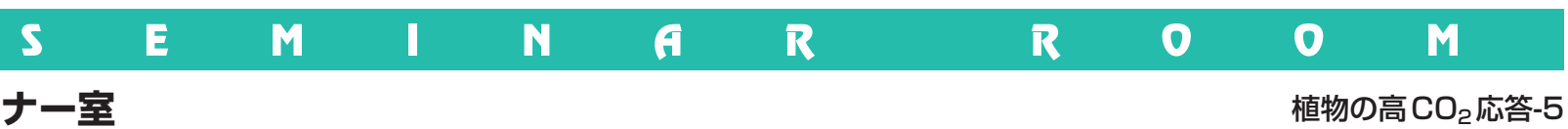

\title{
植物の高 $\mathrm{CO}_{2}$ 応答における遺伝子発現変化
}

\section{深山 浩}

神戸大学大学院農学研究科
はじめに

大気 $\mathrm{CO}_{2}$ 濃度は現在 $400 \mathrm{ppm}$ に達しようとしており， 今世紀末には $700 \sim 1,000 \mathrm{ppm}$ まで増加すると予測され ている。.この大気 $\mathrm{CO}_{2}$ 濃度の上昇は地球温暖化の主要 因と考えられていることから，われわれ人類にとって大 きな社会問題となっている。 また，アジア，アフリカを 中心とした人口増加を考えると, 将来的な高 $\mathrm{CO}_{2}$ 環境 で作物の収量を増大させることは植物研究者の最重要課 題である。これらのことから, 大気 $\mathrm{CO}_{2}$ 濃度の増加が 植物に及ぼす生理生化学的な効果について, グロース チャンバー, オープントップチャンバー, FACE (free air $\mathrm{CO}_{2}$ enrichment: 開放系大気 $\mathrm{CO}_{2}$ 増加）システムな どさまざまな装置を用いて盛んに研究されてきた，そし て近年では遺伝子発現変化, 特にマイクロアレイを用い たトランスクリプトーム解析がモデル植物を中心に行わ れている. 分子生物学的解析技術の目覚ましい発展によ り, 未知の遺伝子の機能解明も進んでおり, ゲノム情報 の量と質が向上することで, トランスクリプトーム解析 の重要性は今後ますます高まると考えられる。また，卜 ランスクリプトーム解析は生理学的に重要な新規の遺伝 子を発見することに扔いても有効である. 本稿では, 高 $\mathrm{CO}_{2}$ 環境下での植物の遺伝子発現変化に関する研究に ついてレビューするとともに，イネのトランスクリプ トーム解析から見いだした, 高 $\mathrm{CO}_{2}$ 条件で発現促進さ
れるCCT タンパク質 $\mathrm{CRCT}\left(\mathrm{CO}_{2}\right.$ responsive CCT protein）について紹介する.

\section{高 $\mathrm{CO}_{2}$ 処理での遺伝子発現変化の特徵と解析にお} ける注意点

高 $\mathrm{CO}_{2}$ 処理による遺伝子の転写産物量の変化を明ら かにするための手法として，2000年代前半までは主に 個々の遺伝子についてノーザン解析, RT-PCR 解析が行 われてきた。そして，2000年代半ばから高 $\mathrm{CO}_{2}$ 応答に おいてもトランスクリプトーム解析が適用されるように なった。トランスクリプトーム解析には塩基配列解析に 基づいたRNA-Seq法, SAGE法やリアルタイムPCRを 利用した方法などもあるが，現在のところマイクロアレ イ法が最も一般的で解析例が多い. マイクロアレイ法は ゲノム情報に基づいて作成された，数千から数万種類の オリゴDNAを固定したマイクロアレイ用スライドガラ スを用いるため, 適用可能な植物種がゲノム解析の進ん だモデル植物に限られる。しかし今後は, 次世代シーク エンサーを用いたRNA-Seq 法によるモデル植物以外の トランスクリプトーム解析例も増えることが期待でき る。これらの方法は, いずれも転写産物のプールサイズ を反映した結果が得られるわけであり, 遺伝子発現が転 写後や翻訳後の段階で制御されている場合は，トランス クリプトーム解析の結果とタンパク質含量や活性の測定 結果が相関しないこととなる。しかし, 転写段階で発現 
調節される多くの遺伝子に関して有用なデータが得られ ることから，トランスクリプトームを解析することが有 意義であることに間違いはない. 高 $\mathrm{CO}_{2}$ 処理した植物 に打ける遺伝子発現変化のマイクロアレイ解析例は多い とはいえないが, シロイヌナズナ, イネ, ポプラといっ た複数のモデル植物で行われてきた ${ }^{(1)}$. 高 $\mathrm{CO}_{2}$ 処理の 特徵として, 塩, 乾燥, オゾンのようなストレス処理に 比べて有意に発現変化する遺伝子の数が少なく, 変化の 程度も全般的に低いことが挙げられる ${ }^{(2)}$. 基本代謝䤉素 では, 高 $\mathrm{CO}_{2}$ 処理による発現変化は高くとも 2 倍程度で ある。これは高 $\mathrm{CO}_{2}$ 処理が植物にとって強い処理では ないことを意味している. $\mathrm{CO}_{2}$ 濃度の違いよりも, グ ロースチャンバーと野外の比較のほうが遺伝子発現の変 化が大きい例も報告されている ${ }^{(3)}$ 。また，野外で行われ るFACE害験の場合は, 天候や気温の変化, 病害虫の 接触などによるストレスを受けており， $\mathrm{CO}_{2}$ への反応が 鈍化することが指摘されている ${ }^{(1)}$.さらに, 高 $\mathrm{CO}_{2}$ 処 理の場合は数週間から数力月間といった長期的な処理を 行うことが多く, サンプリングする時点では転写レベル での応答が低下することもある。.また, 長期的な処理で は処理間での生育のばらつきが生じることから, サンプ ルの発達ステージ，栄養状態などの条件を合わせるのが 困難となる. 植物の生育ステージによって, 高 $\mathrm{CO}_{2}$ に よる光合成関連遺伝子の発現変化の傾向が全く逆になる ことも報告されている( ${ }^{(4)}$.これらのことが要因となって 誤差が大きくなり，意味ある発現変化がその中に埋もれ てしまうことがある。これらのことは，今までに報告さ れている異なるグループが行ったマイクロアレイ解析結 果から, 統一した発現変化の傾向を見いだすことを困難 にしている.イネは生育をそろえやすく, 高 $\mathrm{CO}_{2}$ 処理 をしても葉の展開速度は大きくは変化しないことから,
高 $\mathrm{CO}_{2}$ のトランスクリプトームへの効果を解析するに は良い材料と考えられる。 そこで次に，われわれが行っ たイネを用いたマイクロアレイ解析結果を中心に，植物 で比較的共通して認められる遺伝子発現変化について述 ベることとする.

\section{高 $\mathrm{CO}_{2}$ 処理による代謝関連遺伝子の発現変化}

\section{1. 光合成・基本代謝関連遺伝子}

高 $\mathrm{CO}_{2}$ 条件下では基本的に光合成が促進されるため に光合成産物である糖やデンプンの蓄積が起こる ${ }^{(5)}$. ま た，長期の高 $\mathrm{CO}_{2}$ 処理では葉内の窒素含量の低下が認 められることが多い(5). これらのことから, $\mathrm{CO}_{2}$ 固定, 呼吸, 窒素固定といった基本代謝に関係する遺伝子の発 現が高 $\mathrm{CO}_{2}$ 処理により変化することが予想される。わ れわれはイネの葉身を材料にして行ったマイクロアレイ 解析の結果 ${ }^{(6,7)}$ を用いて, 葉身で主に発現する基本代謝 関連遺伝子をピックアップし，それらの遺伝子に対する 高 $\mathrm{CO}_{2}$ の効果について検討した（図1).まず，自然光 型人工気象室（農業環境技術研究所クライマトロン）で 行った害験では, Rubiscoに代表される $\mathrm{CO}_{2}$ 固定に関係 する遺伝子は発現抑制される傾向があった。また， Rubiscoに $\mathrm{CO}_{2}$ を供給するカルボニックアンヒドラーゼ （CA）も発現抑制された。一方，カルビンサイクルにお いてリブロース-1,5-ビスリン酸 (RuBP) の再生にかかわ るフルクトース-1,6-ビスリン酸ホスファターゼ（FBPase), セドヘプチュロース-1,7-ビスリン酸ホスファター ゼ（SBPase）などは逆に発現促進される傾向があった. それらに加えて, 光合成の最終産物であるデンプン合成 にかかわる ADPグルコースピロホスホリラーゼ（AGPase), デンプン合成酵素（SS）や窒素固定にかかわるグ

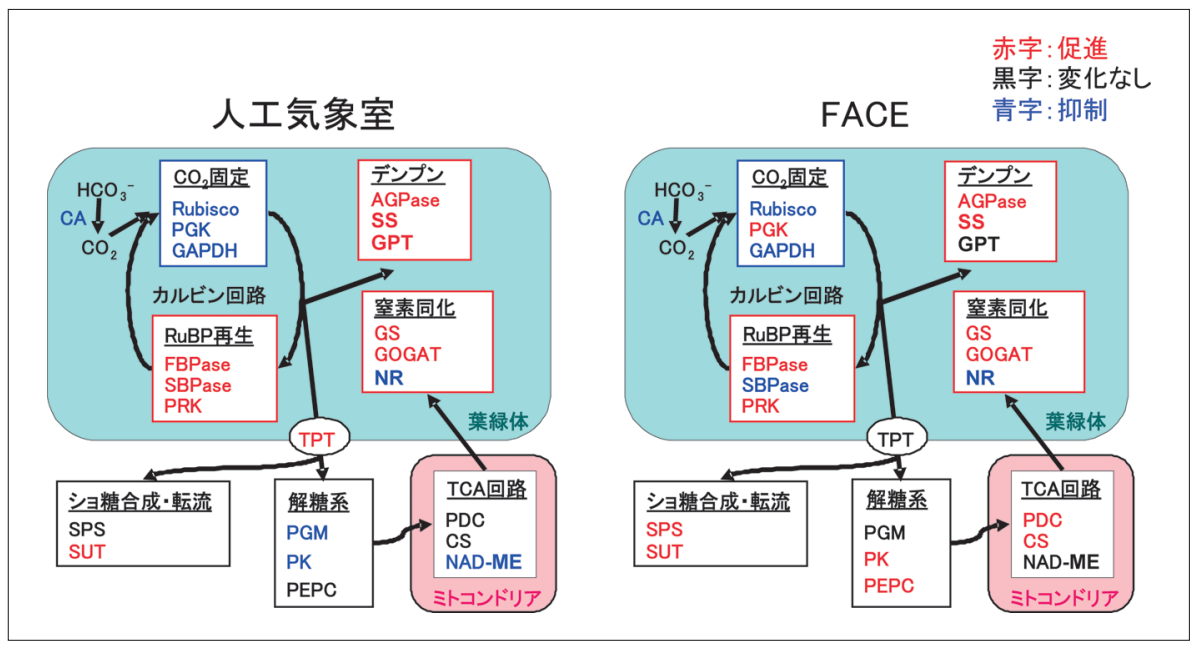

図 1 -高 $\mathrm{CO}_{2}$ 処理がイネの基本代謝 関連遺伝子の発現に及ぼす効果

自然光型人工気象室（農業環境技術 研究所クライマトロン) または FACE（岩手県零石町）においてイ 齐 (人工気象室, 日本晴; FACE, あきたこまち）を異なる $\mathrm{CO}_{2}$ 濃度 (人工気象室, 大気条件 $380 \mathrm{ppm}$ と高 $\mathrm{CO}_{2}$ 条件 $680 \mathrm{ppm} ; \mathrm{FACE}$, 大気条件 $376 \mathrm{ppm}$ と高 $\mathrm{CO}_{2}$ 条件 $\left.568 \mathrm{ppm}\right)$ で 育成し, 葉身に打ける遺伝子発現を マイクロアレイ解析した ${ }^{(6,7)}$. 大気条 件に対して発現促進された遺伝子を 赤，発現抑制された遺伝子を青，発 現変化が認められなかった遺伝子を 黒で示した。 
ルタミン合成酵素 (GS), グルタミン酸合成酵素 (GOGAT), スクロースの輸送にかかわるスクロース輸送体 （SUT）も発現促進される傾向が認められた． $\mathrm{C}_{3}$ 植物の 光合成のモデルによると ${ }^{(8)}$, 光合成の律速因子は $\mathrm{CO}_{2}$ 濃度によって变わり, 低 $\mathrm{CO}_{2}$ から現在の大気条件 ではRubiscoの触媒能力が光合成を律速し, 高 $\mathrm{CO}_{2}$ 条件 ではRuBPの再生能力，デンプンやスクロースの合成・ 輸送がかかわる無機リン酸再生能力が光合成を律速する と考えられている。つまり, イネは高 $\mathrm{CO}_{2}$ 条件下では 律速要因とならなくなったRubisco な゙の $\mathrm{CO}_{2}$ 固定にか かわる遺伝子の発現を減少させて, 律速要因となる $\mathrm{RuBP}$ 再生や光合成の最終産物の合成・輸送にかかわる 遺伝子の発現を増加させたと考えられる.イネで見られ た基本代謝関連遺伝子の発現変化は高 $\mathrm{CO}_{2}$ 下で有利に 光合成を行えるようにコントロールされたものととらえ ることができるかもしれない.このような遺伝子発現変 化は，多少の違いはあるにせよほかの植物種においても 認められている ${ }^{(9,10)}$ 。では，高 $\mathrm{CO}_{2}$ で育成した植物は 高 $\mathrm{CO}_{2}$ 条件での光合成速度が高くなるのだろうか? 答えは全く逆であり, 高 $\mathrm{CO}_{2}$ 条件で植物を育成すると, 高 $\mathrm{CO}_{2}$ 条件での測定であっても, 光合成速度は大気条 件で育成した植物に比べて低下することが多い，この現 象は光合成のダウンレギュレーションと呼ばれている. 光合成が低下する理由として, 高 $\mathrm{CO}_{2}$ 条件で植物を育 成すると葉内窒素含量が減少するため, 与えられた窒素 の各代謝関連酵素タンパク質への分配を最適化させたと してもポテンシャルとしてはマイナスとなること, 遺伝 子発現変化の程度が小さいために大幅な窒素分配の変化 を起こすことができていないことが考えられる，イネに 関しては，高 $\mathrm{CO}_{2}$ 处理をしても二次元電気泳動による 葉内タンパク質の発現プロファイルに大きな変化は起 こっていなかった ${ }^{(6)}$. シロイヌナズナに押いても Rubisco量の減少は認められるが, それ以外の葉内夕ンパク 質の発現プロファイルの変化は少ないことが報告されて いる ${ }^{(11)}$. 先にも述べたように，高 $\mathrm{CO}_{2}$ 処理による遺伝 子発現変化は小さい場合が多く, ここで見られた基本代 謝関連酥素遺伝子の発現変化もほとんどが 1.5 倍以下で あり大きいわけではない。つまり, 遺伝子発現変化が小 さく窒素の分配が大きく変化していない状況で, 葉内窒 素含量が減少するために光合成速度が低下すると考えら れる．窒素含量が減少する分子メカニズムは不明である が，イネにおいては基本代謝関連酵素の中で硝酸還元醳 素（NR）がほかの窒素同化にかかわる酵素と異なり発 現抑制されていた（図1)。イネは窒素源として硝酸よ りもアンモニウムを好んで利用するために葉の硝酸同化
が着目されることは少ないが，高 $\mathrm{CO}_{2}$ によるダウンレ ギュレーションを考えるうえでこの現象は興味深い。

人工気象室と FACEでの実験結果を比較すると, FACEに扔いても扮掠よその基本代謝関連遺伝子の発現 変化は類似していることがわかる(図1)。しかしいく つか違いが認められ，最も大きな違いは呼吸関連酵素遺 伝子の発現がFACEにおいて促進されたことである. FACEにおいては解糖系のピルビン酸キナーゼ（PK）, ホスホエノールピルビン酸カルボキシラーゼ (PEPC) や TCA 回路のピルビン酸デヒドロゲナーゼ (PDC), ク エン酸合成酵素 $(\mathrm{CS})$ といった酵素遺伝子が発現促進さ れた.ダイズ，シロイヌナズナ，ポプラを用いた FACE における実験結果においても, 解糖系, TCA 回路, 呼 吸鎖に関係する遺伝子は有意に発現促進されてい $る^{(10,12,13)}$. また, 高 $\mathrm{CO}_{2}$ で育成した植物では呼吸活性 が高くなること ${ }^{(12)}$ ，ミトコンドリアの数が増加するこ とが報告されている ${ }^{(14)}$. 高 $\mathrm{CO}_{2}$ に㧍いて呼吸関連遺伝 子の発現が促進されるのは，蓄積が増加した同化産物の 代謝や輸送，成長の促進を支えるための炭素骨格の供給 により多くのエネルギーが必要となるためと考えられ る. 特に同化産物の師部への積み込みに使われるエネル ギーは大きく，呼吸で得たATPの約 30\%が使われてい る(15)。ささらに, FACEに㧍いては葉温の上昇などの複 合的なストレスが生じることから，呼吸からのエネル ギーがより多く必要となるのかもしれない。このよう に，FACEに抒けるトランスクリプトームの変化として は呼吸が促進されていることを示唆する結果が多く, そ の要因も理に適っているわけであるが，実際の呼吸活性 に関しては高 $\mathrm{CO}_{2}$ で育成した植物で低下するという報 告も多くある ${ }^{(14,16)}$. われわれのトランスクリプトーム 解析の結果も人工気象室と FACEで異なっており, 呼 吸関連遺伝子の発現と実際の呼吸速度についてさらなる 詳細な解析が必要である。

基本代謝関連遺伝子の中ではデンプン合成・代謝に関 係する遺伝子の発現変化が顕著である場合が多 い(4,6,12). なかでもデンプン合成の鍵酵素である AGPase PS 以外に, グルコース-6-リン酸輸送体 (GPT) が複数の植物において高 $\mathrm{CO}_{2}$ により発現促進されるこ とが報告されている ${ }^{(10,12)}$. Leakeyら ${ }^{(12)}$ によると，ダ イズの高 $\mathrm{CO}_{2}$ 処理においては代謝関連遺伝子の中で GPTが最も大きく発現促進されている。イネに抏いて も GPTはデンプン蓄積が促進される低窒素条件で高 $\mathrm{CO}_{2}$ により顕著に発現促進された，GPTは細胞質から 葉緑体へのグルコース-6-リン酸の取り込みに働くと考 えられる(17). よって, 高 $\mathrm{CO}_{2}$ 条件ではカルビンサイク 
ルを介した経路だけでなく，細胞質由来のグルコー ス-6-リン酸をも利用して，デンプン合成を促進させてい る可能性が考えられる，興味深いことに，弱光下で育成 したシロイヌナズナの生育光強度を増加させた際に, 最 も発現促進されるのも GPTであることが報告されてい

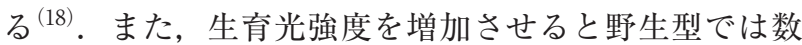
日の間に光合成能力の増加が認められるが, GPT欠損 変異体ではそのような光強度に応答した光合成能力の増 加が認められない ${ }^{(18)}$ 。これらの結果から, GPTは高 $\mathrm{CO}_{2}$ のように光合成が促進されるような環境変化への 適応に重要な役割を担っている可能性がある.

基本代謝関連遺伝子の高 $\mathrm{CO}_{2}$ 応答の中で予想外なの は, 光呼吸に関係する遺伝子の挙動である. 高 $\mathrm{CO}_{2}$ 条 件で光呼吸が抑制されることは自明であることから，光 呼吸にかかわる遺伝子の発現抑制が起こることが予想さ れるが，それらは特に大きな発現変化を示さないことが 多い ${ }^{(19,20)}$. 高 $\mathrm{CO}_{2}$ 処理において Rubiscoの発現量の減 少は多くの植物で認められるが，その減少も植物種によ り認められない場合がある ${ }^{(19)}$. トランスクリプトーム への効果を考えると光合成関連遺伝子の発現抑制より も，デンプン合成・分解や呼吸といった $\mathrm{CO}_{2}$ 固定の後 の炭素代謝に関係する遺伝子の発現変化のほうが顕著で ある ${ }^{(12)}$ 。このような基本代謝関連遺伝子の挙動を見る と, 高 $\mathrm{CO}_{2}$ 条件で過剩となったタンパク質の発現を抑 制するよりも，必要となる蓄積した糖の利用を促進する ような遺伝子発現の応答が起こりやすいように思われ る. また, 高 $\mathrm{CO}_{2}$ 条件では葉内窒素含量の低下も起こ るが, 窒素よりも糖のほうが遺伝子発現に与える効果が 大きいことも報告されて抢り ${ }^{(21)}$ ，このことも糖の利用 に関係する遺伝子の発現変化が見られやすい要因となっ ていると考えられる.

\section{2. 二次代謝関連遺伝子}

二次代謝に関係する遺伝子が高 $\mathrm{CO}_{2}$ 処理により発現 促進されることは多く報告されている(4,13,22). 特に，ポ プラに扔いては高 $\mathrm{CO}_{2}$ 条件下でアントシアニン合成に かかわる遺伝子の多くが発現促進される ${ }^{(13)}$. アントシ アニン合成関連遺伝子はスクロースによって特異的に発 現促進されることがシロイヌナズナにおいて報告されて いる(23)。また，スクロース輸送能力の低下したシロイ ヌナズナ pho3 変異体では葉に扔けるスクロースの蓄積 が起こり，アントシアニン合成に関係するロイコアント シアニジンジオキシゲナーゼ (LDOX) とジヒドロフラ ボノール還元酵素（DFR）が顕著に発現促進される ${ }^{(24)}$. ポプラの高 $\mathrm{CO}_{2}$ 処理においても類似した応答が認めら
れ，LDOX と DFRが $20 〜 40$ 倍と大きく発現促進され る ${ }^{(13)}$. これらのことから高 $\mathrm{CO}_{2}$ の効果により光合成が 促進されて細胞内でスクロースが蓄積し，それによって アントシアニン合成関連遺伝子が発現促進されると考え られる.さらに，ポプラではアントシアニンの蓄積が増 加することにより，葉の光阻害，酸化ストレスに対する 耐性が高まり，落葉が遅延するようである，将来の高 $\mathrm{CO}_{2}$ 環境では紅葉が今よりも美しく, 長期間楽しめる ことになるかもしれない.

\section{3. スクロースに応答する遺伝子は高 $\mathrm{CO}_{2}$ 応答におい て発現変化が大きい?}

高 $\mathrm{CO}_{2}$ で顕著に発現促進されたアントシアニン合成 やデンプン合成に関倸する遺伝子は，グルコースよりも スクロースで効果的に発現促進される ${ }^{(23,25)}$. また, GPTについてもシロイヌナズナpho3 変異体に打いて 約 40 倍に発現量が増加することから ${ }^{(24)}$, 発現にスク ロースが関与していることが予想される。これまでの高 $\mathrm{CO}_{2}$ 応答の遺伝子発現解析についての報告を総合的に 見ると，窒素よりも糖，そして糖の中でもグルコースよ りもスクロースで制御されていると考えられる遺伝子の 方が高 $\mathrm{CO}_{2}$ に対する応答が大きい傾向があるように思 われる．細胞内でグルコースのレベルが高まるには，光 合成によって蓄積されたスクロースが液胞に存在する酸 性インベルターゼの働きにより分解されるスクロース・ サイクリングが必要となる ${ }^{(19)}$ 。つまり, 高 $\mathrm{CO}_{2}$ によっ て起こる代謝的変化の順序からすると, グルコースより もスクロースの蓄積のほうが先となる。また, 酸性イン ベルターゼの活性には種間差があり, 活性の低い種では グルコースの蓄積によって発現抑制されるとされる Rubisco 量の減少が起こらない(19). 高 $\mathrm{CO}_{2}$ 応答におい て主に働いているシグナル伝達系が何なのかという問題 も重要であるが，このような代謝的な側面から考える と, スクロースによって制御される遺伝子の発現変化が 高 $\mathrm{CO}_{2}$ 処理において認められやすいことは妥当な結果 と言える.

\section{高 $\mathrm{CO}_{2}$ 応答における遺伝子発現調節メカニズム}

\section{1. 高 $\mathrm{CO}_{2}$ 応答のシグナル伝達は複雑}

高 $\mathrm{CO}_{2}$ による遺伝子発現変化を引き起こす最も重要 なシグナルは糖と考えられる，糖を感知するメカニズム は複数存在すると考えられるが，ヘキソキナーゼを介す るシグナル伝達が最も知られている。高 $\mathrm{CO}_{2}$ 条件では 光合成が促進されるために光合成組織において糖が蓄積 
し，そのうちのグルコースやフルクトースといったへキ ソースをヘキソキナーゼが感知して光合成関連遺伝子を 発現抑制する ${ }^{(19)}$. また糖レベルの低下が起こった場合 には，プロテインキナーゼSnRK1が基本代謝を含めた 多くの遺伝子の発現調節に働くことが報告されてい る ${ }^{(26)}$ 。その際，トレハロース-6-リン酸がSnRK1の活性 調節に働くこと ${ }^{(27)}$ ，デンプン合成を制御することも知 られている(28).さらに，スクロースに対する応答に関 係するArmリピートタンパク質様ISI1 や MYB 転写因 子 PAP1なども報告されているる ${ }^{(23,29)}$. C/Nバランスの 感知に関係するユビキチンリガーゼCNI/ATL31や転写 因子 $\mathrm{GNC}$ も高 $\mathrm{CO}_{2}$ 応答に関係する可能性がある ${ }^{(30,31)}$. また, 高 $\mathrm{CO}_{2}$ 条件下で変化する可能性のある無機リン 酸, 窒素代謝, レドックスもシグナルとして重要かもし れない $\left.{ }^{(32} 34\right)$.さらに, 高 $\mathrm{CO}_{2}$ シグナル伝達ではオーキ シン, サイトカイニン, アブシジン酸, エチレンといっ た植物ホルモンも関係していると考えられている ${ }^{(35)}$. このように高 $\mathrm{CO}_{2}$ 応答においては多様なシグナルが複 雑に絡み合っている可能性がある。これらのうち $\mathrm{GNC}$, トレハロース-6-リン酸合成酵素，アブシジン酸関連遺伝 子などは高 $\mathrm{CO}_{2}$ 条件で発現変化することが報告されて いるが ${ }^{(9,12)}$, 植物に共通した応答であるのかは不明であ る. 一般的に最も高 $\mathrm{CO}_{2}$ 応答に関係すると考えられて いるへキソキナーゼを介したシグナル伝達でさえも，へ キソース含量と光合成関連遺伝子の発現変化に相関が見 られない場合があること ${ }^{(36)}$, 高 $\mathrm{CO}_{2}$ により発現変化す る遺伝子の多くがヘキソースに応答しないことから ${ }^{(4)}$, 実質的に高 $\mathrm{CO}_{2}$ 応答に扔いて機能しているのかについ ては疑問視されている。つまり, 実際の植物の高 $\mathrm{CO}_{2}$ 応答において個々のシグナル伝達系がどの程度関係して いるのかについては, 現在のところ全く情報が不足して いると言える。

\section{2. 高 $\mathrm{CO}_{2}$ で顕著に発現促進されるCCTタンパク質 CRCT}

われわれは高 $\mathrm{CO}_{2}$ 応答で実際に働いているシグナル 伝達因子を明らかにするために, イネで行ったトランス クリプトーム解析の結果から候補遺伝子を探索すること にした，この場合，できる限り $\mathrm{CO}_{2}$ の効果のみを反映 した結果を用いたいと考元，人工気象室に扔ける結果の みを用いることとした。候補遺伝子を絞り込むに当た り，以下の 4 つの条件を設定した，1）高 $\mathrm{CO}_{2}$ による発 現変化が顕著である，2）窒素のみに応答していない (図2のL-M区)，3）マイクロアレイに扔けるシグナル 強度の平均值が高い，4）遺伝子のアノテーションが遺
伝子発現調節やシグナル伝達に関係する可能性がある. これら4つの条件すべてを満たす遺伝子は, 高 $\mathrm{CO}_{2}$ 条件 で発現促進されるものが 4 個と発現抑制されるものが 4 個の合計 8 個のみであった（図2)。さらに異なる高 $\mathrm{CO}_{2}$ 処理期間, 異なる発達段階の葉を用いて再現性の確認を 行った結果, $C R C T$ と $M-P K$ (マレクチンドメインをも つ受容体型プロテインキナーゼ）の2個の遺伝子に絞り 达むことができた．CRCTは窒素が十分にある条件で は高 $\mathrm{CO}_{2}$ による発現変化は少ないが, 低窒素条件で顕 著に高 $\mathrm{CO}_{2}$ により発現促進された。この窒素に対する 応答性から, CRCT のほうが光合成のダウンレギュレー ションを含めた高 $\mathrm{CO}_{2}$ 応答に関係する可能性が高いと 考え, CRCT の生理機能解析から着手することとした ${ }^{(37)}$.

CRCT はCONSTANSやTOC1 といった転写因子に共 通するCCTドメインをもつタンパク質である. CCT夕 ンパク質はCCTドメイン以外にB-boxやtifyといった Znフィンガードメインをもつものが多いが, CRCTは そのようなドメインをもたない. CCTドメインのアミ ノ酸配列をほかのCCTタンパク質と比較すると, シロ イヌナズナで糖誘導されることが報告されている ASML2 ${ }^{(38)}$ と比較的相同性が高いことがわかった。 し かしASML2はCRCTのオーソログではなく, シロイヌ ナズナにはアミノ酸配列の相同性の高いCRCTのオー ソログと思われる別の遺伝子が 2 個存在する. CRCTは 単子葉植物と双子葉植物が分岐する前から存在する高等 植物に保存された重要な遺伝子であると考えられる。

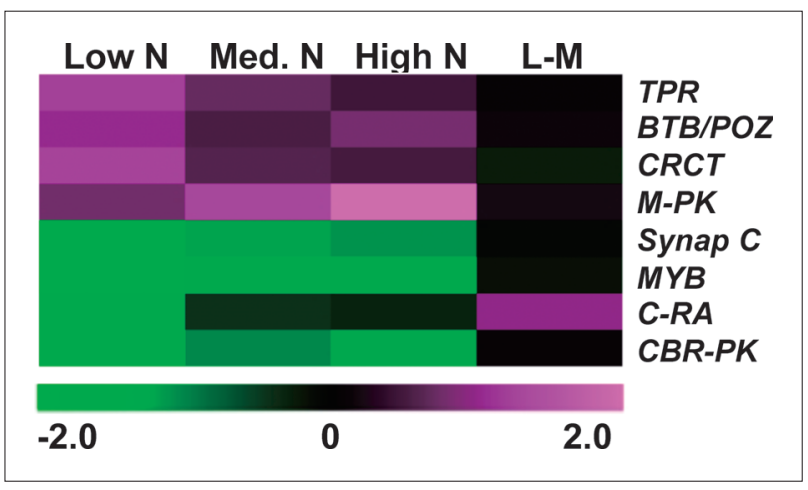

図 2 高 $\mathrm{CO}_{2}$ で発現変化が顕著であったシグナル伝達関連遺伝 子の発現変化

自然光型人工気象室において異なる $\mathrm{CO}_{2}$ 濃度 (大気条件 $380 \mathrm{ppm}$, 高 $\mathrm{CO}_{2}$ 条件 $680 \mathrm{ppm}$ ) と異なる窒素供給量 (Low N, $0 \mathrm{~g} \mathrm{~N}$; Med. $\mathrm{N}, 0.6 \mathrm{~g} \mathrm{~N} ;$ High N, $1.2 \mathrm{~g} \mathrm{~N}$ ) でイネ（日本晴）を育成し，葉身に おける遺伝子発現をマイクロアレイ解析した ${ }^{(6)}$. 大気条件に対す る高 $\mathrm{CO}_{2}$ 条件での遺伝子発現変化 (L-M は大気条件での Med. N に対する Low N の発現比較）の $\log 2$ 值を用いてヒートマップを 作成した。高 $\mathrm{CO}_{2}$ 条件で有意に発現変化した遺伝子の中で, アノ テーションが遺伝子発現調節やシグナル伝達に関係する可能性の ある8個の遺伝子の結果を示した。 


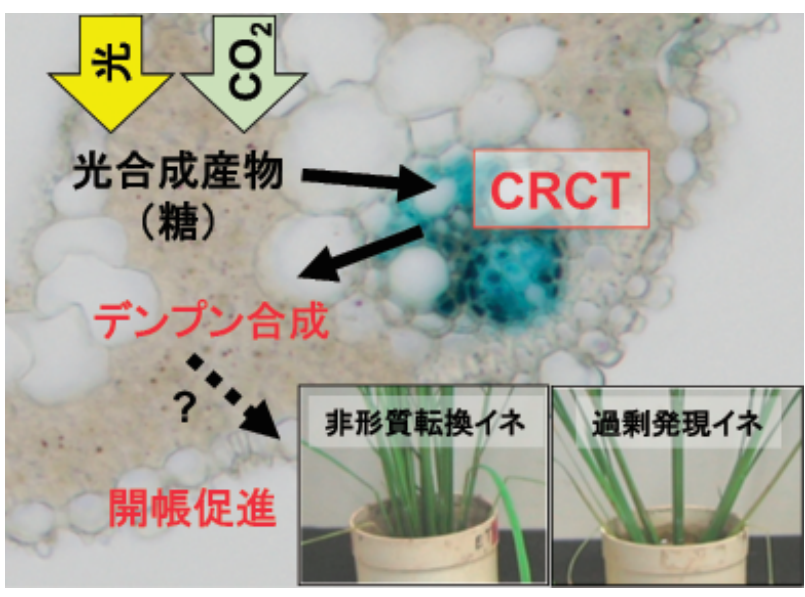

図 3-CRCTの予想される機能

$C R C T$ は葉身，葉鞘，株元などの維管束で主に発現する（図の背 景はCRCT のプロモーターGUS解析おける葉身の横断切片の顕微 鏡写真)。また, $C R C T$ は光合成産物である糖の蓄積によって発 現促進されると考えられる. CRCTはデンプン合成関連遺伝子の 発現調節，株の開帳度の制御に関係すると考えられる.

CRCTは高 $\mathrm{CO}_{2}$ だけではなく糖（特にスクロース） によっても発現が促進される。しかし，2-デオキシグル コース，3-O-メチルグルコースといった代謝できない糖 は発現に効果を与えなかった。2-デオキシグルコースは ヘキソキナーゼの基質となることから $C R C T$ の発現変 化にへキソキナーゼは関与しないことが示唆される。 ま た, CRCTは葉身, 葉鞘, 茎の維管束の師部周辺で発 現し，葉身においては明期の終わりにピークとなるよう な発現の日変化を示した。 これらのことから， CRCT は光合成によって蓄積された糖を維管束で感知して発現 調節されるものと考えられる(図3)。次に, CRCTの 生理機能を明らかにするために, $C R C T$ を過剩発現ま たは発現抑制した形質転換イネを作出し, CRCTの発 現量がイネの生長に及ぼす効果を解析した。その結果, 形態的な違いとして $C R C T$ 過剩発現イネにおいて分げ つ角度（株元の開帳度）が大きくなることがわかった. 分げつ角度に関しては, 分げつ角度の異なるイネ品種を 用いたQTL解析が行われており，最も主要なQTLであ るTAC1が同定されている ${ }^{(39)}$ ．また，重力屈性にかか わるLAZY1が久失すると株が開帳し分げつ角度が大き くなることもわかっている(40)。しかし, CRCTの発現 量は TAC1 や LAZY1の発現に影響を及ぼさなかった. また, CRCTの遺伝子座は報告されているTAC1 以外 の分げつ角度を制御する QTLとも一致しない ${ }^{(41)}$ 。これ らのことから $C R C T$ は品種による分げつ角度の違いに は関係していないが，環境条件により変動する光合成産 物の蓄積量に応じて分げつ角度の調節に働くものと考え られる。
現在, $C R C T$ の生理機能についてさらなる解析を進 めており, CRCTはデンプン合成に関係する遺伝子の 発現調節を担っていることが明らかとなりつつある. 特 にCRCTはデンプン合成における鍵酵素であるAGPase の発現調節に関係している可能性があり，CRCTの発 現量と葉鞘のデンプン蓄積量に正の相関が認められてい る。植物の高 $\mathrm{CO}_{2}$ 応答に扔いて最も明確な代謝的変化 はデンプン蓄積量の増加であり, トランスクリプトーム 解析の結果もそれを裏づけるものであった。イネにおい て葉鞘はデンプンの一次貯蔵組織として機能しており, 出穂前の葉鞘のデンプン蓄積量が最終的な収量の約 $30 \%$ を決定すると言われている。 よってCRCTはイネの高 $\mathrm{CO}_{2}$ 応答, さらには収量の決定において重要な役割を 担うタンパク質である可能性が考えられる。ここで疑問 となるのが, $C R C T$ 過剩発現イネで認められた分げつ 角度の変化とデンプン蓄積量との因果関係である。近 年，葉鞘と稈におけるデンプン蓄積量が低下したイネの AGPase 欠損変異体では，おそらく重力屈性に不具合を 生じることで分げつ角度が増加することが報告されてい る ${ }^{(42)}$. 今後さらなる解析が必要であるが, $C R C T$ 過㮃 発現イネで認められた分げつ角度の変化も，デンプン蓄 積量への効果で説明できるかもしれない.

\section{おわりに}

高 $\mathrm{CO}_{2}$ 環境に高度に適応可能な植物を開発するには, どうすれば良いのだろうか？ そのヒントは，トランス クリプトーム解析の結果が示してくれているように思わ れる，光合成・基本代謝については，高 $\mathrm{CO}_{2}$ 条件にお いて過剩となった $\mathrm{CO}_{2}$ 固定系の酵素, 特に $\mathrm{C}_{3}$ 植物にお いて葉内窒素の約 30\%を占めている Rubiscoを減少さ せ, 律速要因となる $\mathrm{RuBP}$ 再生, デンプン合成, 窒素固 定に関係する酵素を増加させることが重要であろう．植 物は高 $\mathrm{CO}_{2}$ に適応しょうとトランスクリプトームを変 化させているが，その程度が十分ではないために高 $\mathrm{CO}_{2}$ 条件下に扔いて光合成を有利に行うことができていない と考元られる. 高 $\mathrm{CO}_{2}$ 応答における基本代謝䤃素の発 現変化の制御において重要な役割を担う遺伝子を特定 し，遺伝子組換え技術により適切にコントロールするこ とができれば, 高 $\mathrm{CO}_{2}$ 環境での光合成能力の改良に結 びつけることができるはずである. CRCTはその有力 な候補遺伝子の一つと考えられる。 さらにわれわれは, 高 $\mathrm{CO}_{2}$ 環境に適した $\mathrm{C}_{4}$ 植物の活性の高いRubisco を利 用したイネの光合成能力の改良も進めている ${ }^{(43)}$. これ までにイネの Rubiscoの触媒回転速度を50\%増加させる 
ことに成功しており，現在，Rubisco含量の最適化（適 切な量に減少）を行っている。これらの戦略が功を奏す れば, 高 $\mathrm{CO}_{2}$ 条件下での光合成能力の改良, そして収 量の増加も可能となると考えられる. 将来, 現在よりも 美しい紅葉を眺めながら，豊作となったコメを味わいた いものである.

\section{文献}

1) A. D. B. Leakey, E. A. Ainsworth, S. M. Bernard, R. J. Cody Markelz, D. R. Ort, S. A. Placella, A. Rogers, M. D. Smith, E. A. Sudderth, D. J. Weston et al. : Glob. Chang. Biol., 15, 1201 (2009).

2) H. Kanani, B. Dutta \& M. I. Klapa:BMC Syst. Biol., 4, 177 (2010)

3) S. Miyazaki, M. Fredricksen, K. C. Hollis, V. Poroyko, D. Shepley, D. W. Galbraith, S. P. Long \& H. J. Bohnert: Field Crops Res., 90, 47 (2004).

4) F. Kaplan, W. Zhao, J. T. Richards, R. M. Wheeler, C. L. Guy \& L. H. Levine: PLoS One, 7, e43583 (2012).

5) E. A. Ainsworth \& S. P. Long:New Phytol., 165, 351 (2005).

6) H. Fukayama, T. Fukuda, C. Masumoto, Y. Taniguchi, H. Sakai, W. Cheng, T. Hasegawa \& M. Miyao: Plant Sci. 177, 203 (2009).

7) H. Fukayama, M. Sugino, T. Fukuda, C. Masumoto, Y. Taniguchi, M. Okada, R. Sameshima, T. Hatanaka, S. Misoo, T. Hasegawa et al.: Field Crops Res., 121, 195 (2011).

8) S. von Caemmerer \& G. D. Farquhar:Planta, 153, 376 (1981).

9) P. Li, A. Sioson, S. P. Mane, A. Ulanov, G. Grothaus, L. S. Heath, T. M. Murali, H. J. Bohnert \& R. Grene: Plant Mol. Biol., 62, 593 (2006).

10) P. Li, E. A. Ainsworth, A. D. B. Leakey, A. Ulanov, V. Lozovaya, D. R. Ort \& H. J. Bohnert: Plant Cell Environ., 31, 1673 (2008).

11) H. Bae \& R. Sicher: Field Crops Res., 90, 61 (2004).

12) A. D. B. Leakey, F. Xu, K. M. Gillespie, J. M. McGrath, E. A. Ainsworth \& D. R. Ort: Proc. Natl. Acad. Sci. USA, 106, 3597 (2009).

13) M. J. Tallis, Y. Lin, A. Rogers, J. Zhang, N. R. Street, F. Miglietta, D. F. Karnosky, P. De Angelis, C. Calfapietra \& G. Taylor: New Phytol., 186, 415 (2010).

14) K. L. Griffin, O. R. Anderson, M. D. Gastrich, J. D. Lewis, G. Lin, W. Schuster, J. R. Seemann, D. T. Tissue, M. H. Turnbull \& D. Whitehead:Proc. Natl. Acad. Sci. USA, 98, 2473 (2001).

15) J. S. Amthor: Ann. Bot., 86, 1 (2000).

16) B. G. Drake, J. Azcon-Bieto, J. Berry, J. Bunce, P. Dijkstra, J. Farrar, R. M. Gifford, M. A. Gonzalez-Meler, G. Koch, H. Lambers et al.: Plant Cell Environ., 22, 649 (1999).

17) H. H. Kunz, R. E. Häusler, J. Fettke, K. Herbst, P. Niewiadomski, M. Gierth, K. Bell, M. Steup, U. I. Flügge \& A. Schneider: Plant Biol., 12, 115 (2010).

18) K. Athanasiou, B. C. Dyson, R. E. Webster \& G. N. Johnson: Plant Physiol., 152, 366 (2010).

19) B. D. Moore, S.-H. Cheng, D. Sims \& J. R. Seemann : Plant Cell Environ., 22, 567 (1999).

20) J.-J. Van Oosten, D. Wilkins \& R. T. Besford: Plant Cell Environ., 17, 913 (1994).
21) J. Price, A. Laxmi, S. K. St. Martin \& J.-C. Jang: Plant Cell, 16, 2128 (2004).

22) A. Matros, S. Amme, B. Kettig, G. H. Buck-Sorlin, U. Sonnewald \& H. P. Mock: Plant Cell Environ., 29, 126 (2006).

23) C. Solfanelli, A. Poggi, E. Loreti, A. Alpi \& P. Perata: Plant Physiol., 140, 637 (2006).

24) J. C. Lloyd \& O. V. Zakhleniuk:J. Exp. Bot., 55, 1221 (2004).

25) L. N. Sokolov, A. Déjardin \& L. A. Kleczkowski : Biochem. J., 336, 681 (1998)

26) E. Baena-González, F. Rolland, J. M. Thevelein \& J. Sheen : Nature, 448, 938 (2007).

27) Y. Zhang, L. F. Primavesi, D. Jhurreea, P. J. Andralojc, R. A. C. Mitchell, S. J. Powers, H. Schluepmann, T. Delatte, A. Wingler \& M. J. Paul: Plant Physiol., 149, 1860 (2009).

28) M. J. Paul, L. F. Primavesi, D. Jhurreea \& Y. Zhang: Annu. Rev. Plant Biol., 59, 417 (2008).

29) F. Rook, F. Corke, M. Baier, R. Holman, A. G. May \& M. W. Bevan : Plant J., 46, 1045 (2006).

30) T. Sato, S. Maekawa, S. Yasuda, Y. Sonoda, E. Katoh, T. Ichikawa, M. Nakazawa, M. Seki, K. Shinozaki, M. Matsui et al. : Plant J., 60, 852 (2009).

31) Y.-M. Bi, Y. Zhang, T. Signorelli, R. Zhao, T. Zhu \& S. Rothstein : Plant J., 44, 680 (2005).

32) O. Oswald, T. Martin, P. J. Dominy \& I. A. Graham: Proc. Natl. Acad. Sci. USA, 98, 2047 (2001).

33) V. Rubio, F. Linhares, R. Solano, A. C. Martin, J. Iglesias, A. Leyva \& J. Paz-Ares: Genes Dev., 15, 2122 (2012).

34) S. Yanagisawa, A. Akiyama, H. Kisaka, H. Uchimiya \& T. Miwa: Proc. Natl. Acad. Sci. USA, 101, 7833 (2004).

35) N. Teng, J. Wang, T. Chen, X. Wu, Y. Wang \& J. Lin: New Phytol., 172, 92 (2006).

36) F. Ludewig \& U. Sonnewald: FEBS Lett., 479, 19 (2000).

37）森田隆太郎, 杉野充保, 畠中知子, 三十尾修司, 深山 浩：日本作物学会紀事, 82 (別号 1), 186 (2013).

38） T. Masaki, H. Tsukagoshi, N. Mitsui, T. Nishii, T. Hattori, A. Morikami \& K. Nakamura: Plant J., 43, 142 (2005).

39) B. Yu, Z. Lin, H. Li, X. Li, J. Li, Y. Wang, X. Zhang, Z. Zhu, W. Zhai, X. Wang et al. : Plant J., 52, 891 (2007).

40) T. Yoshihara \& M. Ino: Plant Cell Physiol., 48, 678 (2007).

41) Z. Li, A. H. Paterson, S. R. M. Pinson \& J. W. Stansel : Euphytica, 109, 79 (1999).

42) M. Okamura, T. Hirose, Y. Hashida, T. Yamagishi, R. Ohsugi \& N. Aoki : Func. Plant Biol., in press.

43) C. Ishikawa, T. Hatanaka, S. Misoo, C. Miyake \& H. Fukayama: Plant Physiol., 156, 1603 (2011).
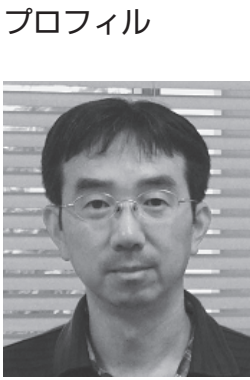

深山浩 (Hiroshi FUKAYAMA) <略歴＞1993年神戸大学農学部園芸農学 科卒業/1998年同大学大学院自然科学研 究科修了, 博士 (学術) /同年生物系特定 産業技術研究推進機構派遣研究員 / 1999 年農業生物資源研究所研究員 $/ 2003$ 年同 主任研究員 $/ 2006$ 年神戸大学大学院農学 研究科助教 $<$ 研究テーマと抱負 $>$ 光合成・ 基本代謝関連遺伝子の機能解析, Rubisco のエンジニアリング, 高 $\mathrm{CO}_{2}$ 応答の分子 メカニズムの解明＜趣味＞テレビでスポー ツ観戦, 海外のボードゲーム 